\title{
Composition, Abundance and Seasonality of Zooplankton in Mida Creek, Kenya
}

\author{
James Mwaluma, Melckzedeck Osore, Joseph Kamau and Peter Wawiye \\ Kenya Marine and Fisheries Research Institute, P.O. Box 81651, Mombasa, Kenya
}

Key words: zooplankton, phytoplankton, composition, abundance, diversity, Mida creek, Kenya.

\begin{abstract}
Samples were collected monthly at four fixed stations in Mida creek from May 1996 to April 1997, in order to determine the species composition, abundance and diversity of phytoplankton and zooplankton collected with 20 - and 332- $\mu \mathrm{m}$ mesh size plankton nets respectively. Sampling also included measurement of salinity and temperature.

Peaks in phytoplankton abundance occurred in May and January, following the long rains in April-May and the short rains in November-December. Zooplankton densities followed the phytoplankton peaks with the main peak occurring in February after the major phytoplankton bloom. Similarly, smaller peaks occurred in May and March.

Copepods dominated the zooplankton forming up to $60 \%$ of total species composition. High zooplankton diversity occurred in June-July when zooplankton abundance was lowest as compared to February-March. Spatially, the highest diversity was recorded at station 1 located towards the open sea as compared to the other stations located farther inshore.
\end{abstract}

\section{INTRODUCTION}

Information on the marine zooplankton of the Eastern Coast of Africa is scanty, except for the works of Sewell $(1929,1932,1947,1948)$ and Smith and Lane (1981) who worked in the western Indian Ocean and did not include inshore waters. Wickstead (1961, 1962 \&1965) studied tropical plankton, while Okera (1974) reported on the inshore zooplankton of Tanzanian waters, and Paula et al. (1998) studied the seasonal cycle of planktonic communities at Inhaca Island in Southern Mozambique. In Kenya, zooplankton species composition, abundance and diversity have been documented for Port Reitz, Tudor creek and Gazi bay, by Reay \& Kimaro (1984), Kimaro (1986), Okemwa \& Revis (1986), Revis (1988), Kimaro \& Jaccarini (1989), Okemwa (1989), Okemwa (1990), Osore (1992, 1994; Osore et al., 1997), Mwaluma (1993) and Kasyi (1994). Mwaluma (1997) documented offshore zooplankton during the Netherlands Indian Ocean Expedition.

This paper presents the results of the spatial and temporal variability in species composition, abundance and diversity of zooplankton in Mida creek, Kenya.

\section{MATERIALS AND METHODS}

\section{Study site}

Mida Creek (Fig. 1) is located at the north coast of Kenya in East Africa ( $03^{\circ} 22^{\prime} \mathrm{S}$ and 39 $\left.58^{\prime} \mathrm{E}\right)$. The total creek area including that covered by mangroves is $32 \mathrm{~km}^{2}$. There is no river drainage into the creek but groundwater enters through seepage along the shores and within the channel bed (Kitheka et al., 1999). In addition to ground water there is also surface runoff inflow during rainy seasons. The dominant water circulation is tidal with a maximum tidal range of $3.2 \mathrm{~m}$ at the entrance and $2.0 \mathrm{~m}$ in the mid-section of the creek

Corresponding author: JM

E-mail:jmwaluma@kmfri.co.ke 


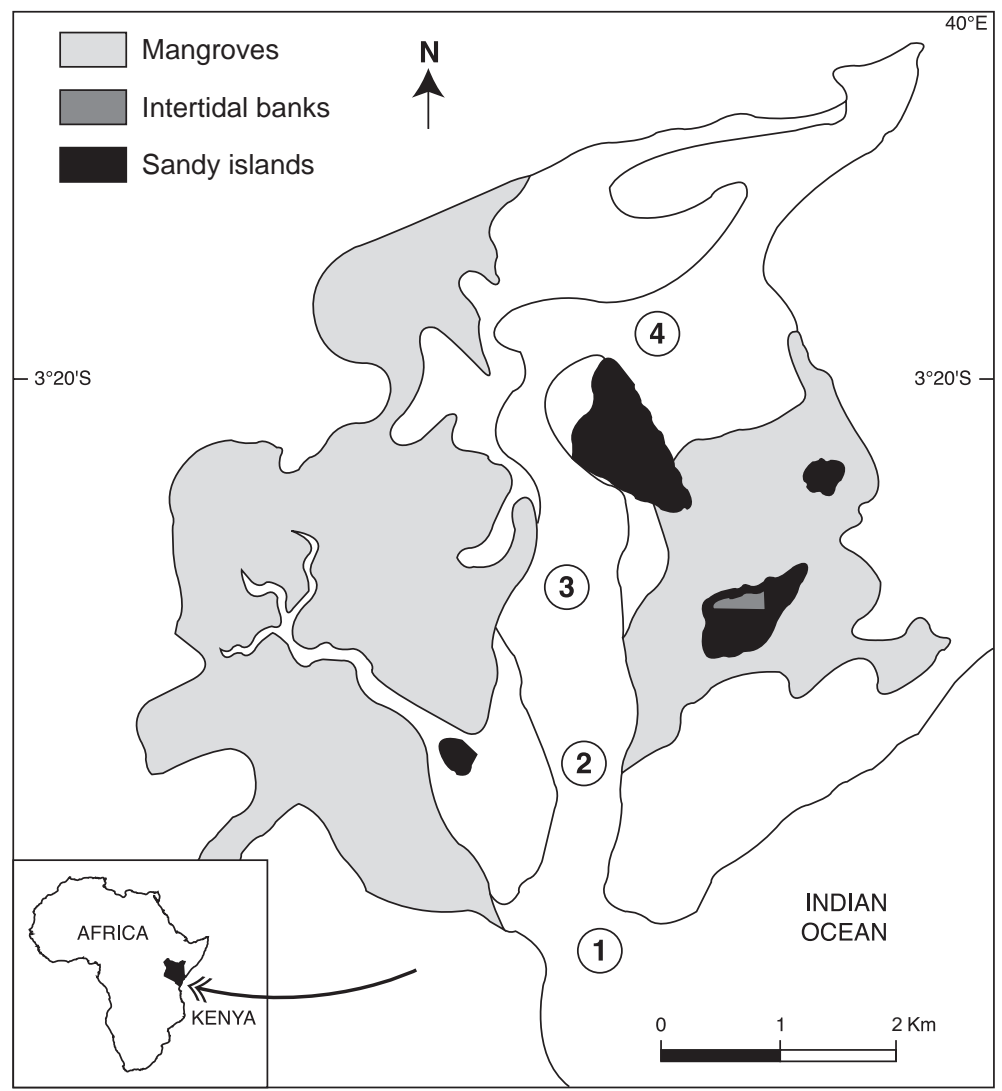

Fig. 1. Location of Mida creek in Kenya, and the sampling stations 1-4 located in the main Mida creek channel

(Kitheka et al., 1999). The dominant climatic seasons are the southeast monsoon (MarchSeptember) and the northeast monsoon (September-March). Annual rainfall is normally 600-1000 mm (G.O.K, 1989), with the highest monthly rainfall normally recorded in May. The evaporation rate is on average $200 \mathrm{~mm}$ per year with a monthly range of 160-210 mm. Air temperature ranges between $24^{\circ} \mathrm{C}$ in July and $32^{\circ}$ $\mathrm{C}$ in February. Mida creek forms an important nature conservation site, as it is part of the Watamu Marine National Park and Reserve under the management of Kenya Wildlife Service.

In order to obtain a comparative account of zooplankton from the different biotopes, four stations were established in April 1996, approximately $2 \mathrm{~km}$ apart beginning at the mouth of the creek to the backwaters (Fig. 1).

\section{Phytoplankton}

Population estimates of surface microphytoplankton were conducted monthly at stations 1, 3 and 4 (Fig. 1). Water samples were collected using a Niskin vertical sampler and sieved through a $20 \mathrm{~mm}$ plankton net. In the laboratory, phytoplankton cells were counted and estimated as number of cells/l after concentrating the sample and taking $1 \mathrm{ml}$ aliquots of the concentrate in a Sedgwick rafter cell.

\section{Zooplankton}

Zooplankton samples were collected monthly from May 1996 to April 1997. Towing for zooplankton was done using a rubber dingy at constant speed of $0.5 \mathrm{~m} / \mathrm{s}$ during high tide, using a 1.5-metre-long Bongo net, with a mouth diameter of $45 \mathrm{~cm}$ and $332 \mathrm{~mm}$ mesh size. The volume of water flowing through the net was measured on a digital 
Hydrobios flow meter. At each station, environmental variables such as salinity and temperature were determined. Salinity was measured using an Artago hand refractometer and temperature using a mercury thermometer. Collected samples were preserved in 5\% buffered formalin for further analysis. In the laboratory, samples were sorted out into different taxonomic groups, identified to the lowest taxa possible and counted under a stereomicroscope after subsampling. The keys and identification references used were obtained from Giesbrecht (1892), Sars (1901), Scott (1909), Sewell (1929, 1932, 1947, 1948), Wickstead (1965, 1976) and Owre \& Foyo (1967), Species diversity was calculated using the Shannon-Weiner diversity index, H (Shannon \& Weiner, 1963).

\section{RESULTS}

\section{Hydrographic parameters}

The highest mean surface water temperature recorded was $31.0 \pm 0.5{ }^{\circ} \mathrm{C}$ in March 1997 during the dry northeast monsoon season, and the lowest temperature was $24.6 \pm 0.1^{\circ} \mathrm{C}$, recorded in July 1996, during the wet southeast monsoon season (Fig. 2). Salinity was similarly highest during the dry spell in February with a mean of 37.3 and lowest in May during the rainy season with a mean of $32.0 \pm 3.2 \%$ (Fig. 2). During this season however, salinity in the inner creek stations 3 and 4 was lower $(27.8-31.4 \%$ ) than that in the outer

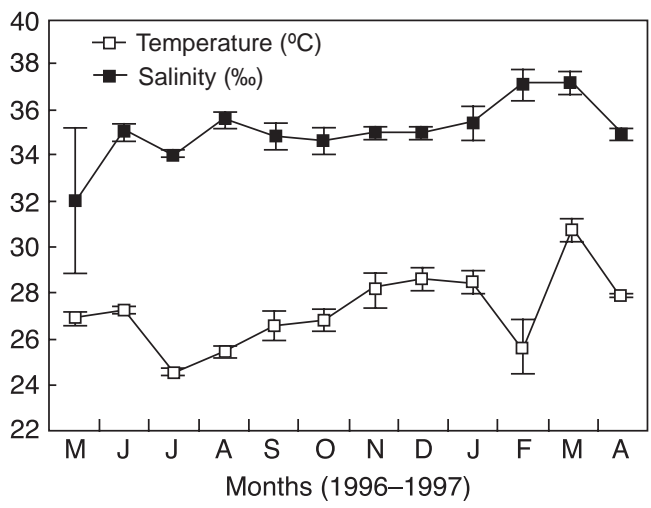

Fig. 2. Monthly variation of temperature $\left({ }^{\circ} \mathrm{C}\right)$ and salinity $(\%)$ in Mida creek. stations 1 and $2(34.5 \%$ ) due to increased ground water influence and surface runoff.

\section{Phytoplankton abundance}

Two peaks in total phytoplankton abundance were observed (Fig. 3). The highest peak was 68,515 cells/l in May 1996 during the long rains, and the other was 65,260 cells/l observed in January 1997 during the dry spell. Two phytoplankton species that were associated with these peaks were Chaetoceros spp. (Bacillariophyta) and Chroccocus limneticus (Cyanophyta) for May and January respectively.

\section{Zooplankton abundance}

Monthly average abundance of zooplankton varied considerably (Fig. 4). A significantly $(\mathrm{P}=0.125)$ higher abundance of zooplankton was found during the NE monsoon (September-March) compared to

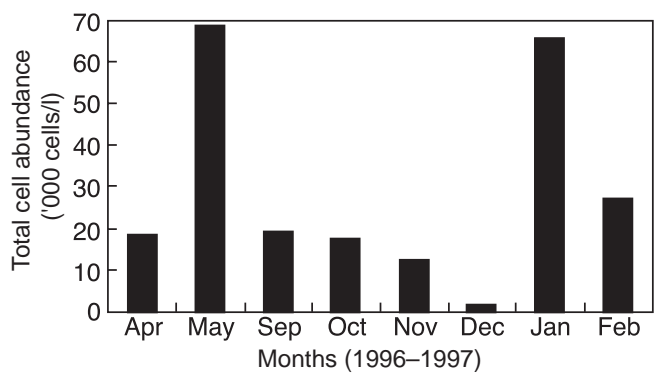

Fig. 3. Total abundance of phytoplankton $\left(10^{3}\right.$ cells/l) in Mida creek

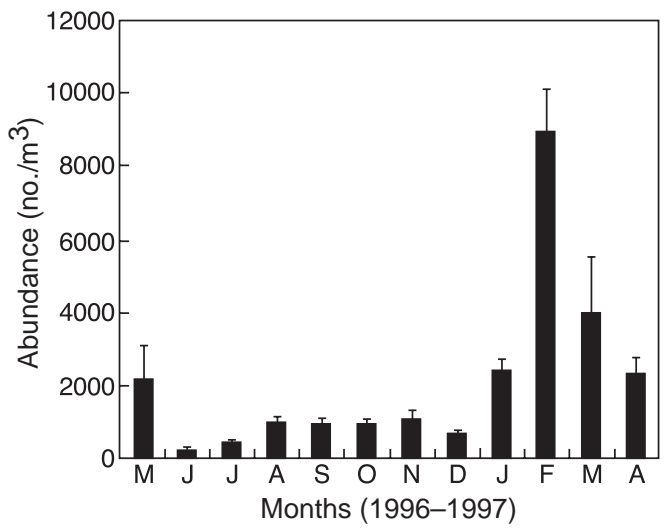

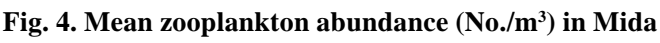
creek 
the SE monsoon (March-September) period.

Peak zooplankton abundance occurred in February 1997, while the lowest abundance was recorded in June 1996 during the cooler intermonsoon period (Fig. 4). Other peaks were recorded in May 1996, March and April 1997 respectively during the rainy season.

\section{Species composition and diversity}

Twenty-seven major zooplankton groups were identified. The dominant groups are shown in Fig. 5. Other groups were Decapoda, including Brachyuran zoea and megalopae, Siphonophora, Euphausiscea, Mysiidacea, Stomatopoda, Amphipoda, Isopoda, Ostracoda, Appendicularia, Sergestidae, Cumacea, Polychaeta, Cirripaedia, Bryozoa, Nematoda, Arachnida and Salpa.

Copepoda dominated zooplankton in abundance throughout the year, forming 35-60\% of total zooplankton composition (Fig. 5). Other dominant zooplankton groups, in order of abundance, were Brachyuran zoea (forming between 10-40\%), Mollusca larvae, Medusae, Chaetognatha, Foraminifera, Caridea larvae and Pisces (fish eggs and larvae).

\section{Copepoda}

The most dominant copepod species were Acartia spp., Eucalanus spp., Paracalanus spp., Temora turbinata and Corycaeus spp. In general, copepod species flourished at different seasons of the year. Most notable was Acartia spp., which had peak density of $1452 / \mathrm{m}^{3}$ in May during the rainy season and Eucalanus spp. which thrived best in February during the dry season with a peak abundance of 952/ $\mathrm{m}^{3}$. Cyclopoida were represented by Oithona spp. Oncaea venusta, Corycaeus spp., Sapphirina spp., Saphirella spp., Porcellidium spp. and Peltidium spp. Harpacticoids were represented mainly by Methis ignea and Setella gracilis.

\section{Brachyuran zoea}

Brachyuran zoea occurred throughout the year, but had maximum abundance $(40 \%$ of total zooplankton) in March during the dry season. They were represented by the families Ocypodidae, Portunidae, Porcellanidae, Grapsidae, Xanthidae, Pimnotheridae, Majidae, Callapidae, Leucosiidae, Hymnosomatidae and others. Amongst the most dominant species were Dotilla fenestrata, Uca vocans, U. annulipes, Macrophthalmus spp., Perisesarma guttatum, Sesarmidae (n.d.) and Phylira spp.

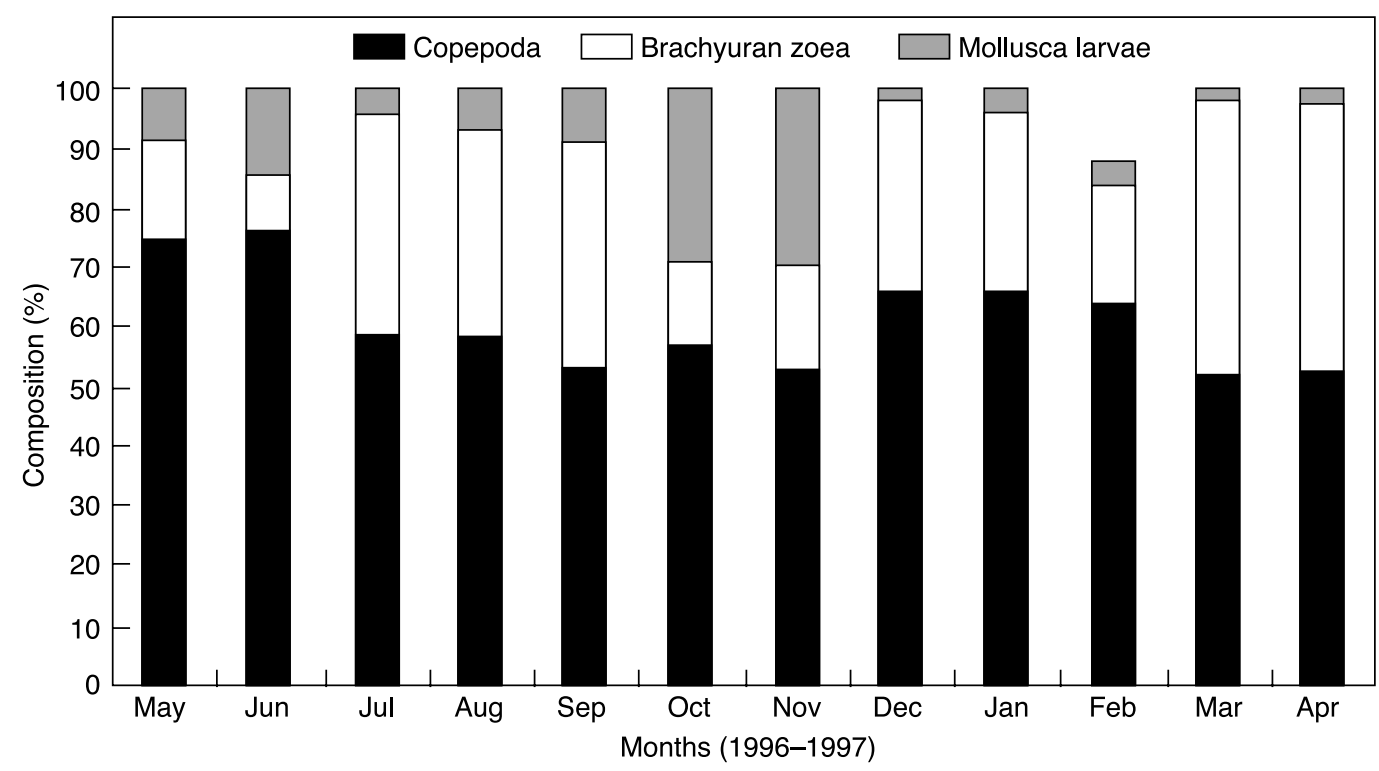

Fig. 5. Percentage composition of dominant zooplankton groups in Mida creek 


\section{Other families}

The mollusca were represented by gastropod larvae and bivalve larvae, heteropods, pteropods, and cephalopod larvae. Medusae were common throughout the year except in June; the highest occurrence was in May during the rainy season. Chaetognatha were found throughout the year, represented mainly by Sagitta spp. mainly during the dry period in February. Foraminifera were present throughout the year except in September. Peak abundance occurred in February during the dry season, represented mainly by Globigerina spp. Caridea larvae were found throughout the year. Peak abundance occurred in February during the dry season. Fish eggs and larvae occurred throughout the year, but had peak abundance in January (Fig. 5).

\section{Statistical analysis}

A Pearson product correlation matrix was calculated in order to determine whether any relationship existed between dominant copepod species and other zooplankton groups. The output is presented in Table 1. From the correlation values (r) obtained, Paracalanus spp. was found to be significantly positively correlated to Eucalanus spp., Mollusca larvae, Caridea larvae, Chaetognatha, Pisces, Brachyuran zoea and Foraminifera. Paracalanus spp. was, however, negatively correlated with Acartia spp. and Medusae. Similarly, abundance of Eucalanus spp. was significantly positively correlated to Mollusca larvae, Caridea larvae, Chaetognatha, Pisces, Brachyuran zoea and Foraminifera. Eucalanus spp. was negatively correlated to Acartia spp. and Medusae. Acartia spp. was significantly correlated to abundance of Medusae and negatively correlated to Temora turbinata, Mollusca larvae, Caridea larvae and Foraminifera. Temora turbinata was negatively correlated with Brachyuran zoea, whereas Medusae was negatively correlated with Mollusca, Caridea, Pisces and Foraminifera. Correlation between Mollusca larvae and Caridea larvae, Chaetognatha, Pisces, Brachyuran zoea and Foraminifera was significantly positive. Caridea larvae were positively correlated to Chaetognatha, Pisces, Brachyuran zoea and Foraminifera.

Mean zooplankton diversity was found to be inversely related to zooplankton abundance (Fig. 6a). High zooplankton diversity was observed between June and July. Peak diversity occurred in July followed by June 1996, this being the period with the lowest zooplankton abundance. Between August 1996 and February 1997, diversity was low (Fig. 6a). During this period however, zooplankton abundance was high, especially in February-March 1997. Mean zooplankton diversity declined from the creek mouth (station 1) to the upper reaches of the creek (Fig. 6b).

Table 1. Correlation coefficients between the abundance of major copepod species and dominant zooplankton groups at Mida creek

\begin{tabular}{|c|c|c|c|c|c|c|c|c|c|c|c|}
\hline & $\mathrm{Pa}$ & E & A & $\mathrm{T}$ & $\mathrm{Me}$ & Mo & $\mathrm{Ca}$ & $\mathrm{Ch}$ & $\mathrm{Pi}$ & B & $\mathrm{F}$ \\
\hline $\mathrm{Pa}$ & 1.000 & & & & & & & & & & \\
\hline $\mathrm{E}$ & $* 0.996$ & 1.000 & & & & & & & & & \\
\hline A & -0.103 & -0.087 & 1.000 & & & & & & & & \\
\hline $\mathrm{T}$ & 0.217 & 0.213 & -0.131 & 1.000 & & & & & & & \\
\hline $\mathrm{Me}$ & -0.193 & -0.181 & $* 0.812$ & 0.176 & 1.000 & & & & & & \\
\hline Mo & $* 0.962$ & $* 0.972$ & -0.121 & 0.256 & -0.173 & 1.000 & & & & & \\
\hline $\mathrm{Ca}$ & $* 0.994$ & $* 0.999$ & -0.076 & 0.211 & -0.176 & $* 0.969$ & 1.000 & & & & \\
\hline $\mathrm{Ch}$ & $* 0.968$ & $* 0.965$ & 0.114 & 0.227 & 0.000 & $* 0.929$ & $* 0.963$ & 1.000 & & & \\
\hline $\mathrm{Pi}$ & $* 0.644$ & $* 0.625$ & 0.206 & 0.419 & -0.007 & $* 0.584$ & $* 0.631$ & $* 0.666$ & 1.000 & & \\
\hline B & $* 0.510$ & $* 0.539$ & 0.259 & -0.045 & 0.095 & $* 0.520$ & $* 0.561$ & 0.468 & 0.426 & 1.000 & \\
\hline F & $* 0.995$ & $* 0.998$ & -0.067 & 0.231 & -0.178 & $* 0.971$ & $* 0.997$ & $* 0.967$ & $* 0.674$ & $* 0.544$ & 1.000 \\
\hline
\end{tabular}

Pa, Paracalanus spp.; E, Eucalanus spp.; A, Acartia spp., T, Temora turbinata; Me, Medusae; Mo, Mollusca; Ca, Caridea; Ch., Chaetognatha; Pi, Pisces; B, Brachuryan larvae; F, Foraminifera.

Marked correlations $(*)$ are significant at $\mathrm{P}<0.05$. $\mathrm{N}=12$ (Casewise deletion of missing data). 

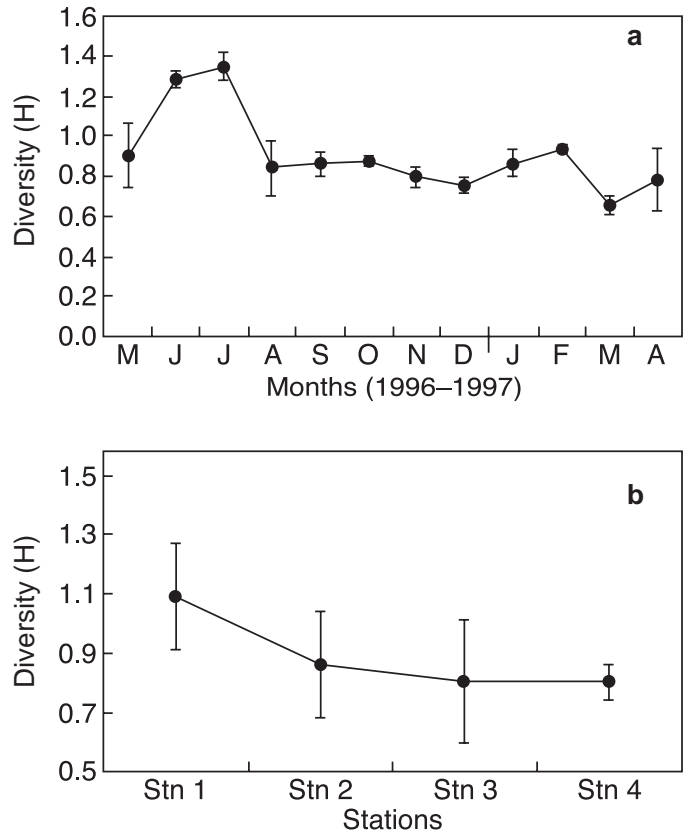

Fig. 6. Mean zooplankton diversity (a) by month and (b) by station in Mida creek

\section{Zooplankton distribution}

Copepoda were distributed in all stations, but the highest distribution was in station 3 , where they formed up to $60 \%$ of total zooplankton composition (Fig. 7a). Brachyuran zoea were more evenly distributed in all the stations compared to any other group. Mollusca larvae were dominant in stations 1 and 2 compared to other stations, whereas Medusae were largely found in station 4 (Fig. 7a).

Chaetognatha were abundant in station 1 and Ctenophora were common in stations 3 and 4 . Caridea larvae were abundantly distributed in stations 1 and 2 and were less common in the backwaters. Foraminifera were common in stations 1 and 2 (Fig. 7b), whereas Pisces were mainly concentrated in stations 1 and 2 .

\section{DISCUSSION}

The abundance of zooplankton and phytoplankton populations in Mida creek follows a cycle closely related to the seasonal cycle of rainfall, as shown by Kitheka et al. (1996) for Gazi bay, Kenya. However, there is no river discharge into Mida creek and nutrients become significantly higher

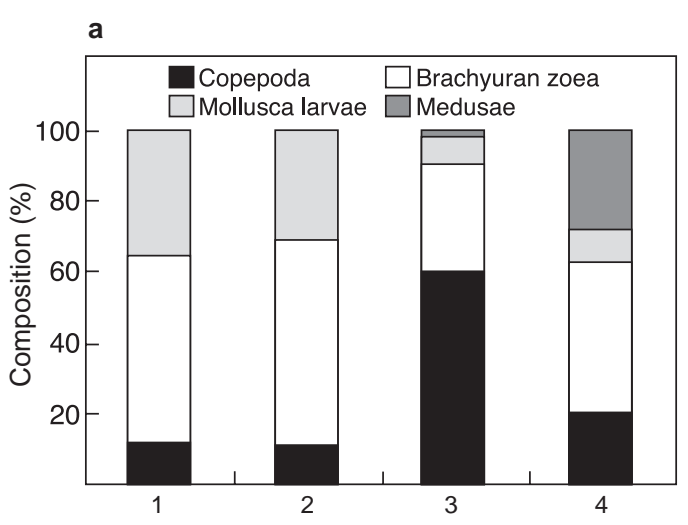

b

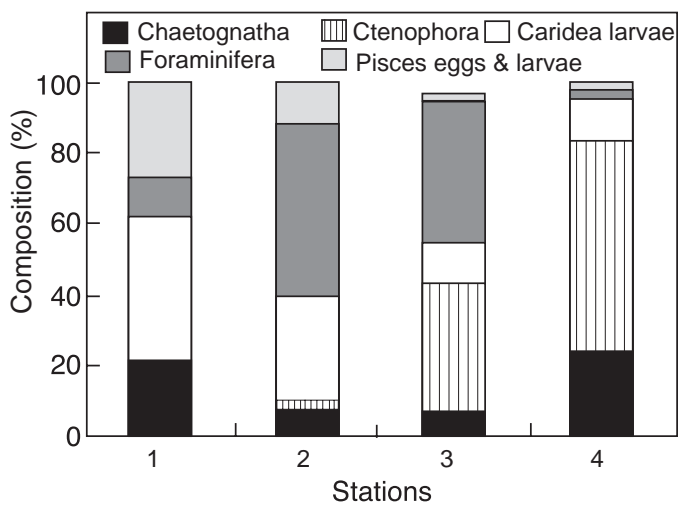

Fig. 7. Distribution (a) and percentage composition (b) of major zooplankton groups at stations 1-4 in Mida creek, May 1996 - April 1997

during the rainy season due to surface runoff and increased groundwater flow from the Mida creek basin (Kitheka et al., 1999). Similarly, peaks in abundance of zooplankton and phytoplankton were seen to follow this trend.

The variation in physico-chemical parameters in Mida creek was also attributed to this seasonality. Salinities were lower during the rainy season, and in the backwaters of the creek vertical salinity stratification was found to occur (Kitheka, 1998). Though generally salinity was constant at $35 \%$, during the rainy season it dropped to $33 \%$ in the frontal zones (stns 1 and 2) and to about $28 \%$ in the backwaters. This drop in salinity was largely attributed to surface runoff and increased groundwater flow in the aquifers that supply the creek.

Similarly, lower water temperatures at 25$26{ }^{\circ} \mathrm{C}$ were experienced from June to September during the SE monsoons, when there was high 
cloud cover, and higher temperatures occurred during the NE monsoon (November to March). Zooplankton in Mida creek seemed to thrive best in the high salinity of the NE monsoon period, though smaller peaks were observed during the rainy season. However, different species seem to be responsible for these peaks, for example the copepods Eucalanus spp. in February (dry NE monsoon season) and Acartia spp. in May (wet SE monsoon). In tropical embayments and estuaries in India, accelerated zooplankton production during periods of high salinity was documented by Madhupratap (1980), Baidya \& Choudhury (1984) and Tiwari \& Nair (1993).

In this study, the copepod families Paracalanidae and Eucalanidae showed a strong positive correlation with each other. They were also positively correlated to other groups like Mollusca larvae, Caridea larvae, Chaetognatha, Pisces, Brachyuran larvae and Foraminifera. A positive correlation between any one or pair of groups indicates that the number of species can increase or decrease in conjunction with one another. This positive correlation provides evidence that these families combine to form a group. The same copepod families were negatively correlated to Acartia spp. and Medusae, meaning that when the number of species in one group increases, the number in the other decreases.

Acartia spp. and Medusae seem to form another group, as they were both negatively correlated to most of the other groups, while remaining significantly positively correlated with each other. Temora turbinata on the other hand seems to have existed on its own, as it was negatively correlated with all the other groups. The group Medusae and Pisces showed negative correlation with each other, meaning the decline in Pisces may have been caused by predation by the Medusae.

Paracalanus spp. and Eucalanus spp. thrived well in the more highly saline NE monsoon season, which may indicate that they were indeed marine in origin. Acartia spp., on the other hand, thrived well during the low-salinity monsoon periods indicating their affinity for brackish waters. Salinity hence, was considered a strong factor governing their seasonality. Tranter \& Abraham (1971, cited in Pillai et al., 1973) identified four factors, which they considered to be important for the coexistence of Acartia spp. in the estuary, viz. tolerance to variable salinity, food supply, generation length and flow. Similarly, the close association of families Paracalanidae, Eucalanidae and other groups may be closely linked to the phytoplankton bloom which occurred in January and May due to their herbivorous nature. These blooms may similarly have contributed as food for the other zooplankton species.

Zooplankton diversity was inversely related to abundance, which was generally higher during the SE monsoon period as compared to the NE monsoon. The lower diversity in the NE monsoon period was caused by high abundance of zooplankton species such as Eucalanus spp. and other dominant groups that emerged during this period. High species diversity was recorded closest to the ocean (station 1) than more inshore (Fig. 6a) as Okemwa (1990), Osore (1992), Osore (1994) and Mwaluma (1997) reported in Tudor and Gazi bay respectively. In India, in the Bay of Bengal and Cochin backwaters, similar trends were reported by Pillai et al. (1973), Nair et al. (1981) and Tiwari \& Vijayyalakshmi (1993), who attributed this high diversity to the calmer, more stable oceanic waters.

The incidence of fish eggs within the entire Mida creek suggests the existence of a breeding ground in the vicinity of this creek. On average, the outer station 1 had a relatively higher abundance of fish eggs than the interior stations (Fig. 7b). Peak abundance occurred in January and February, suggesting a peak breeding season. The occurrence of high numbers of fish eggs in stations 1 and 2 is contrary to the assumption that the inner creek areas are used as nursery grounds. However, the possibility of predation of fish eggs in the inner part of the creek cannot be ruled out, as also highlighted by the negative correlation obtained between Pisces and some of their predators like Medusae.

One limitation of this study was that plankton samples were collected monthly, whereas most plankton processes have a faster time frame. It is therefore difficult to interpret these results conclusively. Dynamic characteristics of plankton distributions in coastal habitats are strongly influenced by tidal currents and salinity gradients, and thus timing of sampling together with spatial 
location in relation to salinity and coastal environment mosaics would determine plankton type and concentration (Paula et al. 1998). For a more in depth analysis, one would need to take into account in the sampling design, a combination of factors like tides (spring and neap), different plankton mesh sizes $(500 \mathrm{~mm}$ for fish eggs \& larvae), diel cycles and vertical distributions in order to compare variability at various scales.

Acknowledgements - This study was made possible by funding from The Netherlands Wetland Program through Kenya Wildlife Service. The authors are grateful for the assistance provided by the wardens and rangers of Watamu Marine National Park and Reserve. We would also like to thank Dr Else Martens Co-ordinator of the Netherlands Wetland Program and Dr Nyawira Muthiga of Kenya Wildlife Service who greatly assisted in logistics.

\section{REFERENCES}

Baidya, A.U. \& Choudhury, A. (1984) Distribution and abundance of zooplankton in a tidal creek of Sagar Island, Sundarbans, West Bengal. Envir. \& Ecol. 2: No. 4.

Giesbrecht, W. (1892) Systematik and faunistik der pelagischen copepoden des Golfes Von Naepal und der angrenzenden meeresabschinitte. Fauna Und Flora des Golfes Von Naepal. 19: 1-830.

G.O.K. (1989) Kilifi District Development Plan 19891999. Ministry of Planning and National Development, Nairobi Kenya, 224 pp.

Kasyi, J.N. (1994) Relationship between nutrient levels, phytoplankton biomass and zooplankton composition, biomass and abundance in Tudor creek. M.Sc. Thesis, University of Nairobi, 99 pp.

Kimaro, M.M. (1986) The composition, distribution and abundance in near-surface zooplankton of Tudor creek, Mombasa. MSc Thesis. University of Nairobi, 95 pp.

Kimaro, M.M. \& Jaccarini, V. (1989) The cycle of near-surface zooplankton abundance in Tudor creek, Mombasa, Kenya. J. Sci. Tech. Ser. B. 10: 7-30.

Kitheka, J.U. (1998) Groundwater outflow and its linkage to coastal circulation in a mangrovefringed creek in Kenya. Estuar. Coast. Shelf. Sci. 47: $63-75$.

Kitheka, J.U., Mwashote, B.M. \& Kamau, J. (1999) Water circulation, groundwater outflow and nutrient dynamics in Mida creek, Kenya. Mang. and Salt. Marsh. 3: 135-146.
Kitheka, J.U., Ohowa, B.O., Mwashote, B.M., Shimbira, W.S., Mwaluma J.M. \& Kazungu, J. (1996) Water-circulation dynamics, water column nutrients and plankton productivity in a wellflushed tropical bay in Kenya. Journ. Sea. Res. 35: 257-268.

Madhupratap, M. (1986) Zooplankton standing stock and diversity along an oceanic track in the western Indian Ocean. Mahasagar. Bull. of the Nat. Inst. of Oceano.16: 463-467.

Mwaluma, J. (1993) Zooplankton studies in a mangrove, seagrass and coral reef system, Gazi bay, Kenya. In: M.A. Hemminga (ed). Second semi-annual report on the STD-3 Project "Interlinkages between Eastern African coastal ecosystems" contract no. T5 3-CT92-0114, Netherlands Inst. of Ecology (CEMO) Yerseke, The Netherlands. pp. 77-82.

Mwaluma, J.M. (1997) Distribution and abundance of zooplankton off the Kenya coast during the monsoons. M. Sc. Thesis University of Nairobi. $90 \mathrm{pp}$.

Mwaluma, J., Osore, M.K. \& Okemwa, E. (1993) Zooplankton studies in a mangrove creek system. In: A. F. Woitchik (ed.). Dynamics and assessment of Kenyan mangrove ecosystems, No. T5 2-0240C (GDF), Final Report. ANCH, Vrije Universiteit Brussel. pp. 74-80.

Nair, S.R.S., Nair, V., Achuthankutty, C.T. \& Madhupratap, M. (1981) Zooplankton composition and diversity in Western Bay of Bengal. J. Plank. Res. 3: 493-507.

Newell, G.E. \& Newell, R.C. (1956) Marine plankton. A practical guide. London, Hutchinson. 244 pp.

Okemwa, E.N. (1989) Analysis of six 24 hours series of zooplankton sampling across a tropical creek, the Port Reitz, Mombasa, Kenya. Trop. Zool. 2: 123-138.

Okemwa, E.N. (1990) A study of the pelagic copepods in a tropical marine creek, Tudor, Mombasa, Kenya with a special reference to their community structure, biomass and productivity. $\mathrm{PhD}$ thesis. Vrije University, Brussels. 225 pp.

Okemwa, E.N. \& Revis, N. (1986) Planktonic copepods from coastal and inshore waters of Tudor creek, Mombasa. Kenya.J. Sci. Ser. B 7: 27-34.

Okera, W. (1974) Zooplankton of the inshore waters of Dar es Salaam (Tanzania, S.E. Africa) with observation to artificial light. Mar. Biol. 26: 13-15.

Osore, M.K. (1992) A note on zooplankton distribution and diversity in a tropical mangrove creek system, Gazi, Kenya. Hydrobiologia 247: 119-120.

Osore, M.K. (1994) A study of Gazi Bay and the adjacent waters: community structure and seasonal variation. M.Sc. Thesis. Vrije Universiteit Brussels. 104 pp. 
Osore, M.K., Tackx, M.L.M. \& Daro, M.H. (1997) The effect of rainfall and tidal rhythm on the community structure and abundance of the zooplankton of Gazi Bay, Kenya. Hydrobiologia 356: $117-126$.

Owre, H.B. \& Foyo, M. (1967) Copepods of the Florida current Fauna. Caribbea 1: 1-37.

Paula, J., Pinto, I., Guambe, I., Monteiro, S., Gove, D. \& Guerreiro, J. (1998) Seasonal cycle of planktonic communities at Inhaca island, southern Mozambique. J. Plankton Res. 20: 2165-2178.

Pillai, P.P., Qasim, S.Z. \& Nair, A.K.K. (1973) Copepod component of zooplankton in a tropical estuary. Indian J. Mar. Sci. 2: 38-46.

Reay, P.J. \& Kimaro, M.M. (1984) Surface zooplankton studies in Port Mombasa during the N. East Monsoon. Kenyan J. Sci. \& Tech. Ser. B 5: $27-48$.

Revis, N. (1988) Preliminary observations on the copepods of Tudor creek, Mombasa, Kenya. Hydrobiologia. 168: 343-350.

Sars, G.O. (1901) An account of Crustacea of Norway. Copepoda Calanoida 4: 1-28.

Scott, A. (1909) The Copepoda of the Siboga Expedition. Siboga Expedite. Monograph. 29 A: $1-28$.

Sewell,R.B.S. (1929) Notes on the surface-living Copepoda of the Bay of Bengal. Rec. Ind. Mus. 8: 313-382.
Sewell R.B.S. (1932) The copepod fauna of the Indian seas. Calanoida. Mem. Ind. Mus. 10: 223 - 407.

Sewell R.B.S. (1947) The free-swimming planktonic Copepoda. Systematic account. Scientific Report on John Murray Expedition. 8: 1-303.

Sewell R.B.S. (1948) The free-swimming planktonic Copepoda. Systematic account. Scientific Report on John Murray Expedition 3: 317-592.

Shannon C. E. \& Weiner, W. (1963) The Mathematical theory of communication. University of Illinois Press, Urbana, 117 pp.

Smith, S.L. \& Lane, P.V.Z. (1981) Biological oceanography of the Somali current data report. Informal data report number 29098. Brokhaven National Laboratory, Upton, New York, 126 pp.

Tiwari, R.L. \& Vijayyalakshmi, R.N. (1993) Zooplankton composition in Dharamtar creek adjoining Bombay harbour. Indian J. Mar. Sci. 22: 63-69.

Tranter, D.J. \& Abraham, S. (1971) Mar. Biol. 11: 222.

Wickstead, J.H. (1961) Plankton of the northern Kenyan banks. Nat. Lon. 192: 890-891.

Wickstead, J.H. (1962) Plankton from the coastal stripes of Kenya and Tanzania area of the Indian Ocean. Nat. Lon. 196: 1224-1225.

Wickstead, J.H. (1965) An introduction to the study of tropical plankton. Hutchinson \& Co., London, 160 pp.

Wickstead, J.H. (1976) Marine zooplankton. The Camelot Press Ltd. Southampton. 59 pp. 